\title{
The humorous dimension of intertextual relations in contemporary Slovak creolized media text
}

\author{
Irina Dulebova \\ Comenius University in Bratislava, Slovakia \\ irina.dulebova@uniba.sk
}

\section{Linda Krajchovichova}

University of Ss. Cyril and Methodius in Trnava, Slovakia

lindakrajco@gmail.com

\begin{abstract}
In the article, we focused on the aspect of humour in the contemporary Slovak media discourse through the prism of the humorous potential of intertextuality. In order to grasp manifestations of intertextuality and understand how the intertextual joke functions, we turned to the concept of verbal and non-verbal precedent phenomenon (as the intertextual code of the linguo-cultural society) established in the modern Russian scholarship.

Through the covers of the popular Slovak weekly .tyžden from 2014-2019 (in total 271 issues of which 90 have an intertextual nature, and 62 of 90 "intertextual covers" can be characterized as "intertextual jokes"), we analyze what types of precedent phenomena are most commonly used in the recent Slovak creolized text and what methods of working with intertext are applied in order to achieve the intertextual joke.

We have come to the conclusion that "the effect of defeated expectation" and the creation of the inconsistency of the connotative meaning of the precedent phenomenon and the situation (context) in which it is used, are the most frequent methods of achieving the intertextual joke.

It was interesting to discover that for the deciphering of intellectual "intertextual riddles" with a humorous effect, Slovak authors predominantly provide the Slovak reader with precedent phenomena connected not with the Slovak, but with the European or worldwide cultural space, or that the visual precedent phenomena are more dominant over the verbal precedent phenomena in conveying the intertextual jokes in the creolized texts.
\end{abstract}

Keywords: Slovak media, humour, intertextual joke, intertextuality, precedent phenomenon. 


\section{1. Introduction. Humour and media in relation to the contemporary society}

Due to the postmodernist paradigm, in which the subversive and centrifugal potential of humour has become an important tool in debunking the centripetal ideological constructs, the scholarly interest in "humour", its manifestations and realizations in the public media discourse has become relevant and topical. This is also due to the fact, that the interesting, controversial and humour belong among contemporary intelligence values (Boyd 1994: 12). Humour plays a very important role in the postmodern paradigm where "instead of coercive orders, hierarchic structure and ideological adherence to humour, the comic subverts these norms" (Lipovetsky 2008: 184).

In relation to the media discourse, the manifestation of humour does not exclusively apply to the phenomenon known as infotainment (an effort to inform in a funny way, but with more emphasis on information than on informing), but also to the penetration of entertaining procedures of humour to the so-called serious, opinion-forming media, whose language has been increasingly penetrated by language tools and language strategies that do not fully adhere to the requirements of fact and factualism. "In the postmodern diction, the general perception of mass media predominantly prevails as an all-pervasive source of entertainment, with the original, journalistic foundation of mass media taking a secondary place in the subconsciousness of the audience" (Lehoczka 2010: 20).

Elements of humor are not characteristic exclusively of tabloids (as opposed to broadsheets), but can also be found in all kinds of media with the intention to entertain the recipient as well as to subject certain phenomena and persons to criticism. Humour is a language of creativity and innovation, it is a very different way of mentally grasping things around us, rather than merely through "the serious language" which until 1989 due to the political regime clearly dominated the information and analytical genre in the Slovak mass media.

\section{Humour}

Since the very complex and wide phenomenon of "humour" is approached by various disciplines and from countless angles (e.g. there are vast philosophical, aesthetic, psychological, literary, sociocultural, or linguistic approaches to humour), humour as such seems to be undeterminable under a single authoritative general theory or a widely accepted and in all cases functional "reliable" definition. "Humour is a far too elusive concept which cannot easily be brought into a laboratory for "an objective" investigation" (Ziv 1984: 97).

As Mikhail Bakhtin suggests, the all-deriding (carnival) "laughter" reflects the "Being" in its resistance to "completeness" and its resistance to being undeterminable by one single "truth". Equally, as our existence, which is an "always developing instance", refutes the attempts of the rationalizing mind to make it "static" and thus fully understandable, therefore, humour also rejects such schematization (Bakhtin 1984: 14). The attempt "to interpret humour is as futile as explaining a spider's web in terms of geometry" (White 1977: 525).

However, we are able to interpret humour in relation to a concrete utterance and in a concrete dialogical process between the author and their recipients, equally as in an intertextual relation between the text and other texts. Any text as an "utterance" (vyskazyvaniye) is an act (postupok) in the dialogical Being (Bakhtin 1979: 185). It responds to the previous texts, previous events, and through the author becomes a subjective reflection of the inter-subjective world (Bakhtin 1979: 8).

On the basis of a text in the public media, we can understand the author's intention, which, to a very large extent, corresponds with the expectation of the readers, since even though an 
analysed medium is a heteroglossic platform: it offers space for a discourse, for contrasting "voices" and conflicting opinions what leads to a dialogization of the world instead of monologizing it, but overall, it represents a certain single "voice" (golos), a way of looking at the world through an embodied ideology by which it attracts and connects with its target audience. In case of the .týždeñ magazine ("Week"), the object of our analysis could be a proEuropean orientation, anti-fascist orientation, as the rising right-wing extremism is currently a huge social problem of Central Europe, or a strong refutation of the current dominant political party which is drowning in corruption scandals. Since the magazine also represents a single "voice", in our analysis, we do not come into contact with all deriding "carnival laughter", but rather with "satirical laughter", i.e., laughter which arises from an ideological position (Sasse 2010: 158). This ideological "voice" is also unified and converged by a "weekly editorial" written by the head of the magazine, who repeatedly labels Slovakia as an "abducted State", that was "kidnapped" by political authorities and needs to be "brought back" to justice. The regular readers of the .týždeň magazine generally accept this ideological position.

As a highly critical medium, .týžden̆ uses the potential of humour to reveal the weaknesses of ideology, order, social and ethical provisions. However, humour is also capable of bringing ideologies to the fore, and thus it is used both as a reaction and a tool (Popova 2017: 15), as it is in the case of the object of our analysis, the covers of the .týżden magazine. On the platform of the .týždeñ magazine covers, "intertextual joke" often arises. Though being often (subjectively) more sad than funny, it always assumes an ideological position (criticism) to one of the current events of the Slovak society.

\section{The magazine .týz̆den̆ (Week) - the object of analysis}

Given its profile (center-right politics, strongly pro-European, but at the same time providing space for both, liberal and conservative views), .týžden̆ is aimed mainly at the educated Slovak subscribers, which also implies a high frequency of use of intertextual links and allusions. The magazine .týždeň is a Slovak political and social weekly, published since 2004, which critically deals with the political situation in Slovakia and abroad. In addition, it also examines culture. We have chosen the .týžden̆ magazine not only because of its unique position on the Slovak media market, and because it is the most popular weekly magazine aimed at the intellectual and highly/educated audience, but also because of its format and frequency of publication, which influences the perception of events. Newspapers are focused on the provision of operational information and most often pay attention to a singular, current event. Magazines also have a longer release cycle and are published after a certain period of time has passed. "On their pages, "the event" is most likely transformed into a "theme", a description of the phenomenon, of which it is a part, and it is drawn to the event in wider interconnections" (Cingerova 2017: 220).

We will analyse covers (which are a classic example of a media creolized text) of all issues of the journal published over the past five years (2014-2019). The specificity of the magazine cover as a genre is the fact that it usually represents the most important topic of the week. The name and the graphic design of the magazine's name (.týžden means „week“) only underlines this fact. "It is a magazine which puts an end to a week and makes a unit out of the week with a single meaning" (Cingerova 2017: 220).

The author of almost all covers of .týžden is Robert Csere, the creative director of the magazine, who has received a number of prestigious world awards for his work as a visual journalist. Apart from him, Vladimira Pcholova (editor's editor), illustrator Natalia Lozhekova, and editor-in-chief Stefan Hrib participate in the creation of the cover design. Robert Csere and Vladimira Pcholova mostly make the design. 


\section{Intertextual joke}

In this article, we focus on the manifestation and conveying of humour in the contemporary Slovak media discourse with regard to intertextuality, through the prism of its use which resolves into an "intertextual joke". The "intertextual joke" is harder to decipher than a joke with no intertextual reference, and in some cases, it can turn for a recipient even into a quiz on the literary and intellectual history (Norrick 1989: 118). But if a certain "socium", in this case the Slovak "intelligence", that comes into regular contact with creolized texts of the .týžden magazine, responds dialogically to the texts and accepts them as utterances playing a role in the public discourse, the society does not only say a lot about the text, but also the text says a lot about the society.

Thus, the analysis of these creolized texts, and the conveying of intertextual jokes in them, has a potential to reveal valuable information about the language image of the world currently present in the Slovak society, what "signs" are repeatedly activated, what precedent phenomena are repeatedly used and what intertextual strategies are employed so that they appeal and "speak to" the readers. The intertextual joke has a potential to reveal a lot of social data about the people that enter into interaction with them - "data on their attitudes, beliefs, group membership, and so on" (Norrick 1989: 118).

Due to the dialogical intentions of the medium, which attempts to be as accessible and referable for its target audience as possible, the authors of the creolized text do not attempt to demonstrate "ideological superiority", but the author rather "presupposes a performer and an audience with shared knowledge of some pre-existent stretch of discourse" (Norrick 1989: 120), so that the audience "demonstrates with laughter the ability to access the appropriately stored item and to hook it up with the current discourse in a new way" (Norrick 1989: 120).

The cover functions as a "complementary exhibition of shared knowledge" (Norrick 1989: 120), and presents to us a valuable source for understanding what intertextual points of reference and what precedent phenomena are present in the Slovak language image of the world - the shared references and shared knowledge.

The following questions are of concern to us:

1. How often does the intertextual joke as a means of communication on the covers of .týždeň arise? How often is the intertextual humour applied as a means of communication? 2. What is the ratio of national-precedent phenomena to international-precedent phenomena? (What is the most occurrent precedent name and what is its stereotypical image? Will the precedent name refer to a Slovak or an international figure?)

3. Do creolized texts (the covers of .týždeň) refer to verbal or visual precedent phenomena? Do verbal or visual precedent phenomena dominate in the conveying of an intertextual joke in a creolized text?

4. How does an intertext, text or a visual image which is being referred to, become humorous? What methods are applied in order to create an intertextual joke in a creolized text?

5. Researches observe two occurring methods of humour in the media text. What method of intertextual joke is more often applied on the .týždeň front cover? Is it a relation to the precedent phenomena that is already humorous in its essence? (e.g., Charlie Chaplin). Or is it by the creation of the inconsistency of the connotative meaning of the precedent phenomenon and the situation (context) in which it is used?

Before we proceed to the analysis, we have to explain the particularities of creolized media texts, the concept of precedent phenomena and their relation to intertextuality, since the object 
of our analysis are creolized media texts and particularly the way in which they convey an intertextual joke.

\section{Particularities of creolized media text}

Today, scholars in the field of media linguistics and mass media communication have observed an enormous increase in the use of the so-called creolized (polycode) texts that consist of several sign systems, verbal and visual, which when perceived through different channels, are integrated and processed by a person in a single universal subject code of thinking, interconnecting visual, structural, semantic, and functional aspects. In the scientific literature (mainly from the field of social semiotics) we also encounter the synonymous concept of multimodal text, but since the term creolized text is more common in the field of philological research, we will use it in our research.

The selection of intertextual references and iconic components of creolized texts in magazines and newspapers is conditioned by the character of the recipient of information: the level of education, social status, sphere of interests, etc. In this case, publicly displayed covers are designed to attract attention not only of the target audience, but also of the disinterested viewer. We can, therefore, assume that the editors of the magazine, graphic designers, illustrators and authors of the text will turn mostly to a more legible intertext (popular songs, anecdotes, political posters, movie posters, popular expressions from the sphere of the cinema and literature, widely replicated pictures, etc.)

The creolized text on the cover of the magazine is perceived as a coherent whole, carrying the humorous component that the compilers of the journal wanted to present to the reader, via the close interaction and coordination of the iconic and verbal components. The connectivity between the verbal and illustrative parts has a pronounced (explicit) character, often in combination with an indirect (implicit) character. In terms of the implicit character, the connectivity of the components of a creolized text is established with a deeper and more thorough analysis of the components, which largely depends on the reader's knowledge of the cultural background. The usage of intertext manifests the sophistication of the author and the reader, who is able to decipher the humorous message that, as we have already mentioned, is potentially not a simple task. In the case of the intertextual joke, the readiness of the recipient is extremely important, and the author has to estimate the linguo-cultural background of their audience and incorporate intertextual element which can be decoded.

\section{Precedent phenomena and intertextuality}

Gasparov aptly pointed out that "so far, the intertextual analysis is more of an art than a science, also because a fundamental question is not yet solved: where does intertextuality end and where does a random match / similarity begin?" (Gasparov 2002: 3). At the same time, J. Kristeva, who has coined the term intertextuality, has broadly expanded the definition of the text, and as a basis for intertextuality labelled not only the text utilized in the language, but also other sign-based systems (e.g., "society", "culture", "history") (Kristeva 1980). The vigorous development of research on intertextuality has resulted in a number of theoretical concepts describing forms of intertextuality through the use of individually designed terminology. Such works include the studies by L. Jenny, J. Derrida, G. Genett, U. Eco, M. Riffaterr, W. Ong, M. Foucault, R. Lachmann, and many others. Scholars constantly work on refining and systematizing the conceptual apparatus of intertextuality, as well as on the boundaries and detailed description of its elements, which has actually become one of the impulses of the contemporary philological research in Russia. Linguists D. Gudkov, V. Krasnykh, Y. Karaulov, 
N. Nakhimova, I. Zakharenko and others follow up on previous theories and develop theses about opening text, intertextuality and reader's position in the dialogical process of interpretation.

For Russian researchers, the basic feature of intertextuality today is the concept of a precedent phenomenon. "Precedent phenomena are phenomena which are: 1) well-known significant parts of a linguistic and cultural community; 2) relevant in cognitive and emotional plan; 3 ) found in the speech of representatives of the corresponding linguo-cultural community" (Nakhimova 2011: 173). Precedent phenomena can be verbal and non-verbal (paintings, sculptures, etc.). Verbal precedent phenomena are subdivided into verbal and verbalizable ones. Verbal precedent phenomena include the precedent name and the precedent usage, and verbalized precedent phenomena include a precedent situation and a precedent text.

Non-verbal precedent phenomena consist mostly of visual images, "expressed through the use of images of objects, paintings, posters, sculptures, events, etc. They represent the result of the objectification of the visual image in textual (iconic and verbal) structures" (Mardiyeva 2012: 42). The precedent verbal-visual phenomena are expressed by means of both sign systems: the precedent verbal phenomenon is reinforced by the visual and vice versa. In this case, it is important that precedent phenomena in both sign systems can be "read" equally clearly and refer to the same source.

It is quite logical that in most cases the precedent verbal-visual phenomena refer to creolized texts which also consist of verbal and visual components. All types of the phenomena, both the verbal (name, utterance, text, and situation), and the visual ones, are closely interrelated, and the use of one of them actualizes the others.

According to Krasnykh, there are social-precedent phenomena, well known to a member of a particular social group, e.g., professional, confessional, generational, national precedent, known to every representative of the given linguistic-cultural community, and universal precedent phenomena which are (hypothetically) known to every homo sapiens and are a part of the universal cognitive space of mankind (Krasnykh 1997: 10). The above-mentioned classifications will serve as a basis of our applied part of the research.

Russian linguist Kuzmina proposes to perceive the cognitive categories of intertextuality and precedence as synonyms, yet it is necessary to demarcate them semantically. According to her, intertextuality is a translation code of culture as a system of traditional human material and spiritual values, and precedence is a phenomenon that can, but does not have to become a fact of culture. Subsequently, the specificity of the media discourse is more associated with precedence than with intertextuality, and precedent texts and expressions are the so-called "influential texts" for a particular linguo-cultural community at a particular time (Kuzmina 2018: 204). Russian scholars correlate intertextuality with timeless cultural values, assuming intergenerational connection, and precedent phenomena with current, contemporary values which means that their existence is limited by the time of reception and reinterpretation, given the likelihood that novelty and significance will diminish in the future (that is the reason why the "support" from readers and constant updating through mass media is important as it provides the widest possible reception for a maximum range of recipients) (Dulebova 2015: 22).

As shown by our previous research, one of the most widespread means of enhancing media discourse expressivity is the transformation (actualization) of precedent phenomena, that is, a deliberate violation of their semantic or structural integrity, since often only by the method of their "remodelling" and adaptation can the author of the text hone their focus in creating a humorous posture. The most widespread way of transforming precedent phenomena in the media discourse today is substitution (replacing), explication (adding), implication (removing), and contamination (linking) of components (Dulebova 2015: 110).

The effectiveness of the use of precedent phenomena to create an intertextual joke in the Slovak media discourse depends on a number of factors, including not only theoretical skills of 
the author of a journalistic text, but also the state of the conceptual systems of readers. The level of understanding the cultural context determines the ability to "discern" the ironic subtext or evaluate the entire pragma-semantic component of a statement "masked" by a humorous effect.

\section{Conveying of intertextual jokes in media texts}

In the process of the analysis of media texts, researchers encounter two cases of forming an intertextual joke: one is based on the humorous essence of the used precedent phenomena (Gargantua, Tartuffe, Charlie Chaplin) and another one is based on "the emergence of the comic effect due to the inconsistency of the connotative meaning of the precedent phenomenon and the situation (context) in which it is used, based on the discovery of a contradiction between essence and appearance of the phenomenon" (Duskaeva 2018: 386). In particular, this involves the cases of creating a humorous effect in describing a situation that is, by its very nature, not comic. It is a frequent contrast between the seriousness of the subject and the look at it by the comic optics.

As Yuryeva demonstrates in her research on the origin of humour in creolized texts, the "effect of defeated expectancy", the absence of what is generally expected and its replacement with the "unexpected" functions as a frequently used device in order to achieve the humorous outcome (Yuryeva 2017: 26). Its use will be explained in our analysis as well, since our research has shown that it is a very frequent element of the humorous covers of .týžder̆.

\section{Methodology}

We have analysed the covers (creolized texts) of all issues of the journal over the past five years (2014-2019). In total, the research corpus consisted of 271 issues, from which we have excerpted (by a continuous sampling method) up to 90 magazine covers using precedent phenomena of different types (verbal, verbalized and non-verbal which are mostly visual). Therefore, these 90 magazines can be labelled as "intertextual covers". In 62 out of 90 cases of the "intertextual covers" it is possible to determine the origin of humorous connotations, which, presumably, can be deciphered even by regular readers.

The creolized texts on the cover of the magazine are perceived as a coherent whole, carrying the humorous component that the compilers of the journal wanted to present to the reader, thanks to the close interaction and coordination of the iconic and verbal components.

With the above stated methods of the conveying of the intertextual joke, equally as with an effect of defeated expectancy, and in accordance with the above stated classification of the precedent phenomena, we have analysed how the intertextual jokes arise and what kind of sources of intertextuality (repeatedly) occur.

\section{Analysis}

\subsection{Universal precedent name and its stereotypical visual image}

One of the most internationally popular precedent names in Slovakia is undoubtedly the name of Napoleon. The name has long gone through a process of simplifying semantics, and of all the multifaceted characteristics of this pronounced historical figure, particularly negative ones, have become ingrained in people's minds. Napoleon has become a metaphorical synonym for excessive ambition, self-confidence, and grandiose plans. It is these semantics that are played 
up in the comic perspective of all four analysed covers which, according to our research, was the most occurring precedent name (figure) on the covers.

In the first case, the well-known painting by Paul Delaroche Napoleon's First Abdication At Fontainebleau is modified and in the other cases it is the worldwide replicated image of Napoleon with his unchanging two-pointed hat.

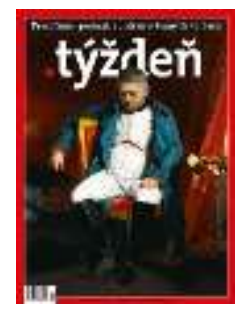

Figure $1(46 / 2017)$

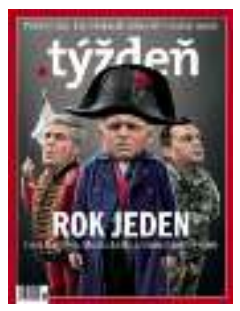

Figure $2(10 / 2017)$

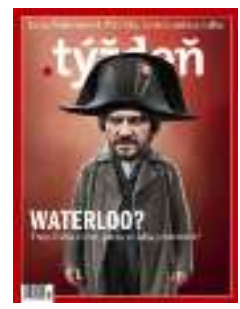

Figure $3(37 / 2016)$

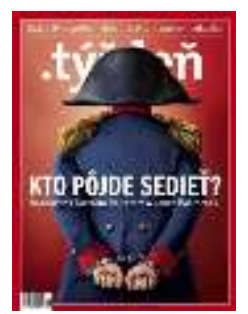

Figure $4(28 / 2016)$

Figure 1-4 reprinted by permission from .týždeň weekly editor in chief Stefan Hrib

In Figure 1, humour is achieved by the occurrence of the "effect of defeated expectancy", the discrepancy between what is expected and what is depicted (Robert Fico's face, the head of the ruling party, Smer (Direction), instead of Napoleon's face), but also by the verbal component Why has Smer (Direction) lost: 20 pages about municipal elections indicating the failure of his ambitious "Napoleon's plans" for municipal elections across the country. Thus, the precedent situation (Napoleon's abdication) is actualized in order to draw parallels between the current situation and the historical event, but despite the parallels, the synthesis of two situations causes a "contradiction between the essence and appearance of the phenomenon" (Duskaeva 2018: 386), as Robert Fico does not achieve the "importance" of Napoleon. It is a contradiction between what is "historically" and "precedentially known" and what is "local and contemporary".

In Figure 2, not only do we see the image of Then-Prime Minister Robert Fico in the uniform of Napoleon and with a far from triumphant look, but also the humorous disagreement of military uniforms juxtaposed from historically different times, which indicate disagreements in the parliament during the first year of government. Behind the Prime Minister Robert Fico, we can see, in different uniforms, two leaders of other political parties that are in coalition. Year one, the heading itself as a verbal component without a hint of humour, emphasizes the satirical intention of the author: if during the first year so many contradictions appeared, then what future lies ahead of "the political warriors"?

Figure 3 actualizes the famous precedent situation of the Battle of Waterloo (1815) in the metaphorical well-known sense of a synonym for the total defeat, the last desperate but unsuccessful attempt to win the decisive battle and save the situation. The discourse strategy of authors, depicting in the image of Napoleon Interior Minister Robert Kalinak, who had to resign after massive anti-corruption protests across the country, is concretized by the heading (verbal component) Waterloo, which refers to a precedent situation.

In Figure 4, we observe the contradiction between the significance of the figure of Napoleon and that of Robert Kalinak. Due to the verbal part of the creolized text titled Who will go to jail?, the authors point out the case of the corrupt behaviour of the Prime Minister who, despite massive protests, refuses to give up housing in the Bonaparte housing complex which belongs to tax fraudster Basternak (now sentenced).

As we can see, the most frequent precedent name used on the covers of .týžden̆ magazine is a name which refers to an international figure. This points to the fact that the Slovak audience is very open to international precedent phenomena, and since the politicians are an object of mockery, the precedent name of Napoleon is in all cases used to refer to a popularized idea of 
"negative characteristics" of the historical figure, such as excessive ambition and unhealthy ego. The visual precedent phenomena are a part of the Slovak image of the world, in which the idiom "Napoleon complex", involving Napoleon as a referent to such negative characteristics, is frequently used.

In all of the cases, we do not observe the reference to the precedent phenomena which are humorous by their essence, but "the inconsistency of the connotative meaning of the precedent phenomenon and the situation (context) in which it is used" (Duskaeva 2018: 386). In figure 2, the contradiction between essence of the phenomena and their appearance between Napoleon's ambitions and what has been achieved by the Prime Minister is viewed as an object of mockery. In figure 4, we equally observe the inconsistency between the essence of the phenomena and their depiction, since Napoleon's figure is depicted in handcuffs and contextualized in the contemporary context. Napoleon again evokes ambitions in the connotative plan, but the handcuffs and the title Who will go to jail? contradict these ambitions.

However, figure 1 refers to the abdication of Napoleon and figure 3 refers to the Battle of Waterloo, which are both precedent situations that connote loss and failure. Since the Prime Minister and the interior minister are also found in the situation of failure, due to their corruption scandals, the essence of the phenomena and their depiction are not situationally in contradiction. This can be interpreted even as a manifestation of the desire shared by .týžden̆ and its readers to see the dominant political party lose its power as Napoleon did. However, the intertextual joke is conveyed by the connection of figures of a local political meaning with a world-known historical figure. In this aspect, "influential" Napoleon synthetized with the Prime Minister, or with the Interior Minister of Slovakia, is a "contradiction between essence and appearance of the phenomenon" (Duskaeva 2018: 386), as the "world-known and historical influence" is contextualized through the "local and contemporary" meaning.

\subsection{Universal-precedent visual phenomena (in the form of well-known paintings) and their actualization}

As our observation shows, the treasures of the European art are a very popular source of intertextuality in the creolized media texts. In all of the six following creolized texts, the longstanding precedents of antique and biblical situations are actualized in the visual form of the images.

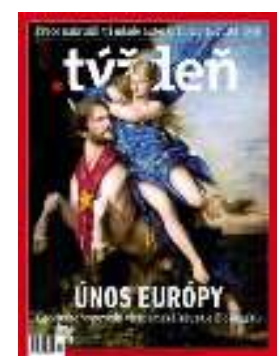

Figure $(22 / 2018)$

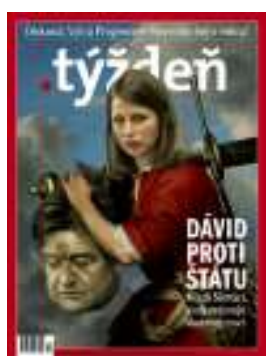

Figure $6(50 / 2016)$

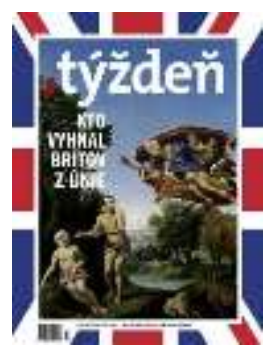

Figure 7 (27/2016)

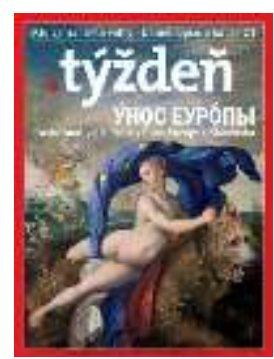

Figure $8(47 / 2014)$

Figure 5-8 reprinted by permission from .týždeň weekly editor in chief Stefan Hrib

In Figure 5, we can see a modified painting by Simon Vouet The Rape of Europa, in which the ancient story is put into context with the contemporary political figure, Interior Minister Robert Kalinak, and the current political discourse: the head of the Ministry of Interior R. Kalinak is depicted instead of the head of a bull, and Europe is wrapped in the flag of the European Union. The cover is a reaction to the international scandal of the Slovak government aircraft which was used to kidnap entrepreneur Trinh Xuan Than after the diplomatic visit of Vietnamese representatives in Slovakia. The subheading What does the Vietnamese affair say 
about Slovakia? extends the semantics of this creolized text to the question of the values of the Slovak government under the Smer political party. Interior Minister Robert Kalinak, who according to .týždě̆, holds responsibility for the act of abduction, just like Zeus, transforms in the picture into a bull and led by his greed, he abducts Europa, but not Europa - the Phoenician woman who was unwillingly abducted and sexually assaulted. He abducts the European Union as a symbol of values. Thus, the discrepancy between the original myth and the contemporary situation is highlighted by Europe dressed in a European flag. However, the humorous effect arises primarily out of the synthetization of Zeus and Interior Minister Robert Kalinak. "A contradiction between essence and appearance of the phenomenon" is the contradiction of displaying the Interior Minister as an "all powerful mythical God".

In Figure 6, the painting of David with the Head of Goliath (Jacob van Oost the Elder) was used in combination with a precedent of the biblical story, actualized by the verbal component David against the state (young Slovaks who resist corrupt power). The head of David is replaced by the head of young Slovak anti-corruption activist Zuzana Hlavkova, who revealed a dubious tender during the Slovak Presidency of the Council of the European Union, and the head of Goliath is replaced by the head of Minister of Foreign Affairs M. Lajcak. Similarly, as in the original biblical story of David and Goliath, we observe the dichotomy between the "vulnerable and morally good" and "strong and morally bad". We observe a humorous situation in which the strong visual representation of opposites emphasizes the moral and emotional sense of the world, and it opposes the ideal to the real, in the form of ridiculing the latter (Vasilyeva 2017: 87). However, what makes this association humorous is the "effect of defeated expectancy". Instead of seeing the David and Goliath, as we are used to due to the popularity of the biblical story, we see "the local and contemporary", Hlavkova and Lajcak.

Figure 7 represents the transformation of the painting by Domenico Zampieri The Expulsion of Adam and Eve (depicting the biblical precedent of expulsion of Adam and Eve by God from Paradise). In the original picture, Adam points to Eve as a culprit, but the humorous situation in the creolized text is made thanks to the unexpected exchange of God's face for the President of the European Commission Jean-Claude Juncker, the face of the evil Eve for Boris Johnson's face, while instead of Adam's face there is the face of David Cameron blaming Eve, in this case Boris Johnson. The comedy of the situation is also exacerbated by the verbal component of the creolized text, which is created by the rhetorical question Who drove the British out of the European Union? (In this case, the European Union is compared to paradise, and the humour of answering a similar question lies in the word nobody, because it is them who are expelling themselves from the European Union). "The effect of defeated expectancy" occurs again, since instead of seeing God's face, we see the face of David Cameron, and instead of Eve, we see Boris Johnson. "A contradiction between essence and appearance of the phenomenon" is the contradiction between the "real" and "currently happening" on one hand, and between the "biblical" and "sacral" on the other.

An interesting example is Figure 8, which demonstrates a rather frequent case of a deliberate use of the Cyrillic alphabet in the Slovak media to create a humorous impression, the signs do not correspond with their connotative meaning, as the Cyrillic alphabet is used to express the Slovak words. Thus, the effect of defeated expectancy takes place. This creates a new "screen of images" and it is very projective for a Slovak recipient, since the "paraphrase" of the title of the picture "The Rape of Europa" by Maarten de Vos remains in Slovak but the Russian alphabet is used. The heading of the issue printed on the cover in the Cyrillic alphabet reads: "The Rape of Europe". The subheading clarifies: "The Russian Endeavors for Cultural Rape of Europe and Slovakia". In the Slovak media discourse, the Cyrillic alphabet is used in various ways. On the one hand, it is used in various multimodal texts with a purpose of underlining "Russianness", or as reference to the Russian cultural space, and on the other hand, it has a potential to act as a carrier of aggression (Cingerova 2017: 219), as it does in this case. 
The Cyrillic title is an example of the signified "qualities" (aggression), but not only does it refer to the "rape of Europe", it also "steals" the Latin alphabet, and therefore, metonymically (a part instead of the whole) also abducts the European writing, literature, and culture - the civilizational foundations of Europe. The humorous effect is strong for the recipient of the text, who is as a rule able to decode the text if they remember the period during which the Russian language was a compulsory school subject. This example is a reminder of the time of the Eastern Bloc and all that remains of it in the collective memory.

The visual collage corresponds with the verbal component. In the original myth, Zeus transforms into a bull in order to abduct Europe. However, here the precedent phenomenon is a "bear" which connotes Russia and is associated with the "Russianness" that abducts Europe who is holding the flag of the European Union, making it explicit that the myth is used again in the European Union associating dimension.

Therefore, "the contradiction between essence and appearance of the phenomenon" (Duskaeva 2018: 386) takes place equally visually and verbally. Visually, the remodelling of the myth puts a bear as a stereotypical sign of "Russia" instead of a bull as Zeus. Verbally, the used alphabet does not conventionally correspond with the language in which the utterance takes place. Both of these situations also cause the "effect of defeated expectancy" since the title is written in the Cyrillic alphabet instead of Latin. Instead of seeing a white bull (or at least a bull) abducting Europe, the percipient sees a bear.

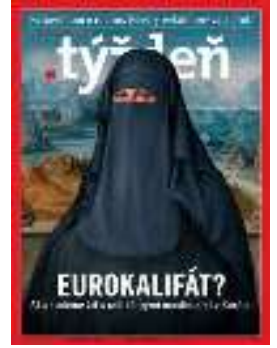

Figure $9(05 / 2015)$

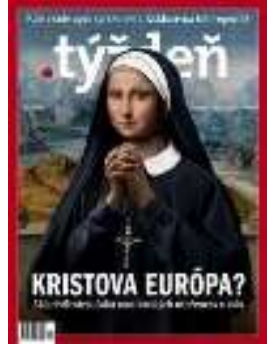

Figure $10(42 / 2015)$

Figure 9-10 reprinted by permission from .týždeň weekly editor in chief Stefan Hrib

Not only was mythical Europe abducted by Zeus, but also Mona Lisa (La Gioconda), the most famous work of Renaissance genius Leonardo da Vinci, has become a symbol of the "European values", depicted comically on the magazine covers of .týždeřn, which is probably due to the fact that the painting is notoriously well-known and thus any transformation becomes immediately noticed. We see Mona Lisa transformed into the image of a Catholic nun (Figure 10) and a veiled Muslim woman (Figure 9). In both cases, the verbal component represents a question of the European values. In Figure 9, we can see a challenging neologism "European Caliphate" presented with a question mark. In Figure 10, we observe the precedent expression "Christ's Europe", and the question mark which questions true values of Europe.

In both figures 9 and 10, the "inconsistency of the connotative meaning of the precedent phenomenon and the situation (context) in which it is used", manifests itself through remodelling Mona Lisa as a symbol of "Europe". In figure 9, the precedent phenomenon connoting European culture (Mona Lisa) is set into the cultural context of the Middle East (wearing a face-covering robe). We, therefore, observe the "contradiction between essence and appearance of the phenomenon" as a contradiction between the cultural context in which Mona Lisa originated and the situation into which she has been set. The "effect of defeated expectancy" takes place as instead of seeing notoriously famous Mona Lisa's smile, the recipient sees Mona Lisa in a robe, with her face being covered. 
In figure 10, the inconsistency of the connotative meaning of the precedent phenomenon and the situation (context) in which it is used, arises out of situating Mona Lisa, a product of the Italian Renaissance, into "cloisterly" setting. The recipient is again confronted with the "effect of defeated expectancy", since instead of seeing Mona Lisa with her hands down and with a mysterious smile, they see Mona Lisa in nun clothes and in a praying position. The precedent phenomenon of Mona Lisa is used in both pictures as a connotation of Europe, and at the same time, its remodelling ridicules the anti-globalistic views.

\subsection{The legacy of the Soviet narrative}

The 40-year stay of the Czechoslovak Socialist Republic in the Socialist Bloc headed by the USSR, when "With the Soviet Union Forever" posters were hanging all over Czechoslovakia, could not help but leave a strong mark on the cultural memory that still today relentlessly extends to a number of intertextual references (not only in the media discourse) to iconic plaques, paintings, photographs, statements, situations, and personalities of the period.

In the analysed covers of the magazine .týżden published within the last five years, we have encountered allusions to the Russian (Soviet) cultural space 10 times, which is close to the number of references to the Slovak cultural space. Thus, the reference to the international precedent phenomena of the Soviet-connoting character is approximately as frequent as references to the national-precedent phenomena.

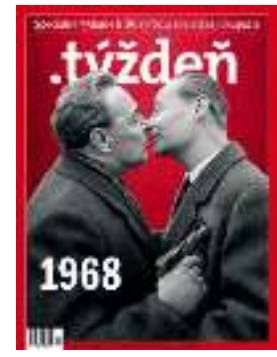

Fugure $11(34 / 2018)$

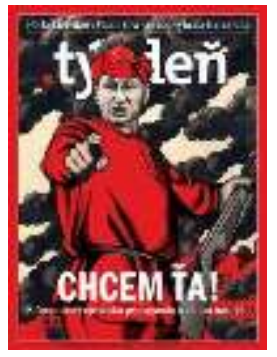

Figure $12(25 / 2015)$

Figure11-12 reprinted by permission from .týždeň weekly editor in chief Stefan Hrib

In Figure 11, we can see a sarcastic actualization of the well-known precedent situation of the Brezhnev kiss (the Fraternal kiss, a popular way of greeting of Leonid Brezhnev, the General Secretary of the Central Committee of the governing Communist Party of the Soviet Union), which is till today often derided and laughed at. Here we observe the activation of the precedent phenomenon which is not made "humorous" by the transformation, but is rather humorous in its essence, as kissing Brezhnev was and still is considered to be "funny". Nevertheless, we do observe an occurrence of "the effect of defeated expectancy", since the recipient, who immediately remembers the precedent situation of Brezhnev's eager kissing, does not expects to see a pistol in Brezhnev's hand. By using the unexpected visual accessory (the pistol in Brezhnev's hand), the creolized text points at the hypocrisy of the Soviet diplomacy. The Brezhnev's kiss connotes the diplomatic affability, but the heading 1968, which refers to the precedent year in which Warsaw Pact troops' invasion of Czechoslovakia took place, is placed near the pistol pointed at Alexander Dubček, the leader of Czechoslovakia under whom the liberalization of the Czechoslovak society took place and who was forced to resign after the Soviet invasion of Czechoslovakia. "The contradiction between essence and appearance of the phenomenon" is the contradiction between the essence of the Soviet propaganda which stylized the Soviet Union as a "liberator from imperialism", with its hypocritical "affability" embodied in Brezhnev's act of kissing Dubček, and between its "appearance" brought to the inter- 
subjective reality of the events, which is depicted metonymically by the gun pointing at Alexander Dubček. The gun as a part represents the military aggression as a whole.

Figure 12 refers to the precedent creolized text, the most prominent Soviet agitation poster Are you among the volunteers? created by the artist D. Moore in 1920 (inspired by the American poster I want you for U.S. army) which depicts the aggressive, urgent position of the Bolshevist soldier and emphasizes the urgency of the challenge, with a finger pointed at the recipient, using the familiar form of addressing the audience instead of the respectful form. The position of the soldier has become iconic and is often used in creolized texts as well as in various Internet memes. Thus, the soldier of the iconic poster has become a precedent image. Besides being symptomatic, it always addresses the audience in a familiar way. "I want you!" is the message of Putin who is dressed as a Red Army soldier, and the subheading "Where is the Russian propaganda heading" refers to information war (Figure 12). The "effect of defeated expectancy" takes place, since instead of seeing the face of a soldier as a part of the well-known image, the recipient sees the face of Vladimir Putin. Correspondingly, the "human perception, prone to fixing at first abnormal phenomena, predetermines the creation of a deformed fragment of reality that causes laughter" (Sakharova 2007: 329).

\subsection{National - precedent phenomena}

In the course of the analysis of our selected creolized text corpus, we found that there are considerably fewer actualizations of the intertextuality associated with the native Slovak cultural space than with the international space, as in only 11 out of 90 texts with the intertextual components were also present the precedent phenomena of the national-precedent character.

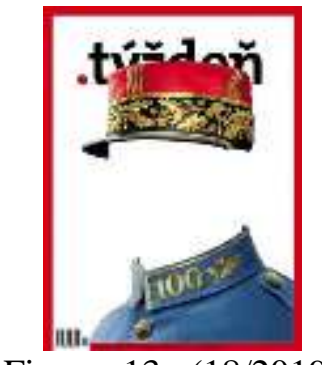

Figure $13(18 / 2019)$

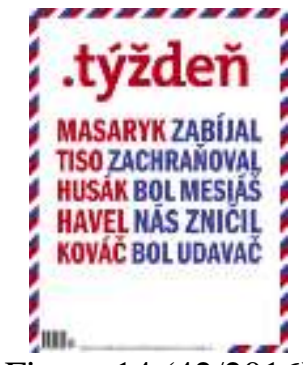

Figure $14(42 / 2016)$

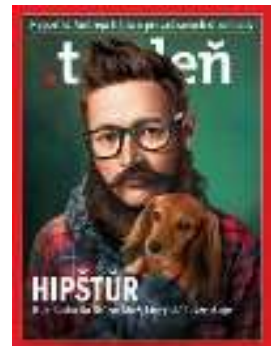

Figure $15(37 / 2015)$

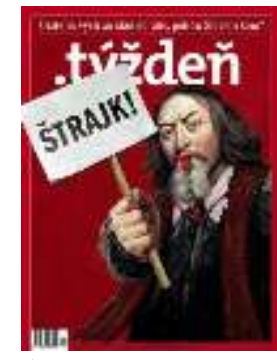

Figure $16(4 / 2016)$

Figure 13-16 reprinted by permission from .týždeň weekly editor in chief Stefan Hrib

Figure 13 presents an actualization of the visual precedent phenomenon, the notoriously known photograph of general M. R. Stefanik (1880-1919). The portrait is well-known to every Slovak from school textbooks, since it is a portrait of one of the founders of Czechoslovakia in 1918. In Slovakia, the given national-precedent name of historical origin is glorified. As a figure playing an important role in the Slovak cultural memory, his portrait used to be seen by every Slovak on the most valuable banknote, before Slovakia adopted Euro as its currency in 2009. In addition, this precedent name in 2019 was intensively actualized in the public discourse as $\mathrm{M}$. R. Stefanik became the winner of the nationwide poll "The Greatest Slovak". At the same time, the centenary of his death was widely celebrated throughout the whole country.

As we can see, "the effect of defeated expectancy" is achieved by removing the face of Milan Rastislav Stefanik from his portrait, so notoriously known in the Slovak cultural space that the recipient automatically substitutes the well-known face in the picture, but at the same time wonders why the face is absent. The absence of Stefanik's face can be understood in two ways: that the "real face" of the national hero is still little known, as well as the fact that nothing else but the outer cover remained from the historical legacy of Stefanik. Although the semantics 
of the references given by itself is not humorous, the method of modifying the notoriously known image is humorous by the way it remodels the iconic photography.

The second example of the creolized text (Figure 14) seemingly appears as a verbal text with a number of significant precedent names of the Slovak linguistic cultural space, but there is a visual component which is the colour-based allusion to the Slovak tricolored white-blue-red flag, highlighted by the colours of the flag around the perimeter of the cover. Its role is to underline that these are the most important Slovak statesmen. The humorous effect stems from the "upside-down" characteristics of the presented officials that are disseminated in so-called conspiracy media and are in full contradiction with their historical deeds (founder and president of the first Czechoslovak Republic Masaryk killed people, President of the fascist Slovak State Tiso saved people, secretary of the Communist Party of Czechoslovakia and president of the Czechoslovak Socialist Republic was a messiah, Havel, the leading figure of political changes in November 1989 destroyed us, and first President of the modern Slovak Republic Kovac was an informer).

The reader encounters negative conspiracy insights which are to be found in "alternative" conspiracy media. Due to them being placed under each other, the absurdity of such statements accumulates, what makes the sarcastic intention of the author: to displace the statements as "ridiculous", more explicit. We encounter a world which is turned "upside down", in which the history becomes rewritten and the precedent names obtain the opposite meaning of what they connote in conventional utterances of cultural memory. Thus, the "contradiction between essence and appearance of the phenomenon" (Duskaeva 2018: 386) is the contradiction of how precedent names function among educated readers, and how they appear in the text and among the conspiracy media. The dictator of the fascist regime becomes a "saviour", while Havel, the first president of Czechoslovakia who helped to liberate the state from the Soviet influence, is depicted in the text as "a destroyer". The application of humour as the "contradiction between essence and appearance of the phenomenon" (Duskaeva 2018: 386) in this case functions as social criticism. It displaces the world of conspiracy media as something "laughable" and ridiculous. The "defeated expectancy" of the recipient occurs as well, since the reader of the .týždeñ magazine expects the precedent names to be associated with the opposite associations as those given in the text. The visual component, the connotation of the Slovak flag by means of colours, intensifies the social criticism. The worldviews which turn the history "upsidedown", and are therefore "laughable", are contextualized with the Slovak flag as a possible state of the country and point at the dark side of its public discourse.

Figure 15 achieves the humorous effect by "the contradiction between essence and appearance of the phenomenon" (Duskaeva 2018: 386) by displaying prominent Slovak revivalist, politician, philosopher and linguist Ludovit Stur (1815-1856) in modern clothing, accessories, and with a hipster hairstyle. This depiction of the "old" in the "modern" is accompanied by the verbal component of the creolized text whose capital lettering shows the occasionalism Hipstur (as an emphasis of his hipster image in the picture), but also the subheading written under in small text: The Year of Ludovit Stur: the man who does not stop to raise excitement.

If the non-humorous message of the creolized text is to communicate that the legacy of Stur is still relevant to the Slovak society, the humorous depiction lays in depicting the $19^{\text {th }}$ century revolutionary as a contemporary "hipster" with a dog and a stylish haircut. The effect of defeated expectancy takes place from both sides of "the new" and "the old". The recipients do not expect to see a hipster as a precedent figure, nor do they expect to see the national hero stylized as a hipster. The humour here is applied in order to raise the reader's curiosity, who will potentially want to read the entire magazine and learn more about what is still unknown and exciting about Stur two hundred years from his birth. In essence, the article is a reinterpretation of some of the 
well-known aspects of his deeds, which were far from amusing, but the cover with its humorous charge has a potential to increase the reader's interest.

Figure 16 combines "the old" with "the new" and "topical" as well, but this time the humour is less displayed for the sake of humour and is conveyed as social criticism. The activation of the precedent name of Jan Amos Comenius (the biggest state university in the capital city of Slovakia is named after him), a distinguished Czech pedagogue and humanist of the 17th century, is also an actualization of positive associations with the term "education", as the precedent name of the "father of modern education" refers to "education" in a positive light. The poster Strike put into his hands and the whistle in his mouth refers to the (at that time) ongoing national strike of teachers, who were striking for better work conditions and more money in the school system. The precedent name, which connotes positive associations of education, is contextualized with the contemporary problem. Since Comenius is whistling and holding the sign Strike, the connotation of "a good education system", which his precedent name connotes, is used to support the strike of teachers. The strike is here represented as legit from the point of the mission of education.

Once again, the intertextual joke is conveyed as an "effect of defeated expectancy" as the reader does not expect to see the precedent historical figure (precedent name) in a position to support the contemporary issue. In both cases of activation of the precedent names of Stur and Comenius, we observe the trend of creating an intertextual joke by remodelling the precedent figure on the basis of its situatedness in the contemporary contexts.

In addition to the 16 analysed examples, the research material gives a lot of stimuli for the analysis of intertextual allusions used in the creolized text on the covers of the magazine .týžder (2014-2019). As we have observed, 90 intertextual covers of .týždeň involve 17 references to popular European and American films, 19 famous paintings, 7 fairy tales, 17 precedent statements of literary and historical origin (almost all in their actualized form), 26 precedent names - real and imaginary anthroponyms.

\section{Conclusion}

The universal-precedent phenomena (79) prevailed over the national-precedent ones (11), in a proportionally dominant 7:1 ratio. The higher usage of the universal-precedent phenomena in the Slovak media discourse is not solely characteristic of the magazine .týžden but we have already observed the trend in our previous research of the Slovak media discourse (Dulebova 2017: 172). It is an interesting phenomenon, worthy of an extensive linguo-cultural analysis and anthropological and philosophical interpretation, which can reveal much about the Slovak language picture of the world. We can only speculate whether this trend is caused by Slovakia being a relatively small state, while in Russia, on the contrary, national precedent phenomena seem to dominate over the universal ones.

Correspondingly, the most often used precedent name was the international precedent name, referring to the internationally well-known figure of Napoleon. The precedent name was repeatedly used in intertextual jokes which degrade politicians of the Smer political party that the .týždeň magazine opposes due to its corruption scandals. The precedent name of Napoleon in the texts connotes "ambition", "greed", but also "end" and "failure", which makes it a very functional tool for the conveying of jokes with political intentions.

In relation to the two occurring methods of intertextual humour in the media text: 1. A relation to the precedent phenomenon that is already humorous in its essence and 2. the creation of inconsistency of the connotative meaning of the precedent phenomenon and the situation (context) in which it is used, the second method is clearly more often put into the use than the first one. Only in 11 cases out of 62, intertextual jokes were the object of reference already 
humorous by their nature, as, for example, in the precedent situation of the Brezhnev kiss in figure 11, which even received the name ,the triple Brezhnev“. In most of the cases, the object of intertextual relation was a precedent phenomenon not humorous by its nature, as for example, Mona Lisa (in figures 9 and 10), the myth of Zeus abducting Europe and its adaptation in the famous works of art (in figures 5 and 8) or the precedent names (historical figures), as Ludovit Stur (Figure 15). As our analysis demonstrates, in order to achieve the humorous outcome by the conveying the second method, a certain remodelling of the precedent phenomena which is referred to, as a rule, takes place. Remodelling the precedent phenomenon by means of its contextualization with the current reality and events is the most frequent way of conveying intertextual jokes in the case of the .týžden̆ magazine.

This trend is also conditioned by the nature of the journal, which attempts to evaluate the most crucial event of the current week, and the contextualization of what is "precedent" with what is "new" and "topical" functions as an occurring and logical method, since what is "precedent" gives to what is "topical" a new and more concretized meaning, which corresponds with the ideological standpoint of the .týžden magazine and its regular readers.

Anti-corruption activist Zuzana Hlavkova becomes David from the biblical story of David and Goliath, (then) Prime Minister Robert Fico becomes sad Napoleon in the moment of his abdication, and Russia metonymically depicted by a stereotypical bear abducts Europe instead of Zeus as a white bull. All of these intertextual jokes allow us to see the current social and political issues through the optic of the intertextual plan, through the activated meanings and their dialogical interaction with the meanings of the present time.

The frequently mentioned "effect of defeated expectancy" allows for the humorous to arise without the movement in the intertextual plan of meanings and their activation. One does not expect to see kissing Brezhnev holding a gun, or the famous pedagogue Comenius holding a poster and a whistle, or the nineteen-century revolutionary Ludovit Stur dressed as a "hipster". Such intertextual joke does not rely on the act of interpretation and does not expect the recipient to understand the intertext. However, due to the precedent character of the object of relation (e.g., arguably every Slovak knows the face of Ludovit Stur and Milan Rastislav Stefanik), the remodelling of the precedent phenomena becomes "funny".

As our analysis shows, the method of the creation of inconsistency of the connotative meaning of the precedent phenomenon and the situation (context) in which it is used and the method of the creation of a defeated expectancy in humorous intertextual creolized texts function often simultaneously. On the more primitive plan, seeing Mona Lisa as a nun or as a Muslim woman becomes "funny" simply because it creates an atypical estrangement of what was already conventionally expected. But on the more complex intertextual plan, we observe how the famous painting is associated with the "European" values, and how its retransformation points at the different worldviews. Subsequently the idea of a "muslimized Europe" or a purely "Christian" Europe becomes "funny" instead of Mona Lisa herself.

In regard to the question whether verbal or visual precedent phenomena dominate in the intertextual joke present in creolized texts, our research concludes that visual precedent phenomena (e.g., paintings) dominate over the verbal ones in the $68 \%: 32 \%$ ratio. This is probably due to the humorous potential of visual images. The precedent expression "Christ's Europe" becomes humorous only when contextualized with transformed Mona Lisa, while the transformed Mona Lisa is self-sufficient in creating a humorous effect. And while the verbalized precedent phenomenon (as a precedent situation) "Waterloo" in Figure 3 is necessary to concretize the meaning of the image (and explain the distressed face of the Interior Minister as a Napoleonic figure), it is a visualized precedent of Napoleon and its retransformation that makes the humorous effect possible. Therefore, visual intertexts become activated more often, as they make it easier for the recipient to understand the humorous meaning. 
Based on the analysis of 90 creolized texts of intertextual nature (out of 271 covers published in five years), 62 could be characterized as an "intertextual joke", which is not only intertextual but also humorous. Our research shows that intertextual joke is not only usable, but also a frequently used method of a social commentary and social criticism.

\section{Acknowledgements}

This article has been prepared within the framework of the grant scheme KEGA Course Book Political Linguistics 015EU-4/2019.

\section{References}

Bakhtin, M. (1984). Rabelais and His World. Indiana University Press. Bloomington: Indiana University Press.

Bakhtin, M. (1979). Estetika slovesnogo tvorchestva. Moskva: Iskusstvo.

Boyd, A. (1994). Zpravodajstvi v rozhlase a televizi. Praha: Centrum nezavisle zhurnalistiky.

Cingerova, N. (2017). 'The Function of Cyrillic Script in Slovak Public Discourse', in Khokhlova, M. \& Monakhov, S. (eds.). Proceedings of the 45th international philological conference (IPC 2016). Sankt-Peterburg: Atlantis press, pp. 219-222.

Dulebova, I. (2015). Precedentne fenomeny suchasneho russkogo yazyka. Bratislava: UK v Bratislave.

Dulebova, I. (2017). 'Precedent names-anthroponyms in Slovak political media texts', in Duskaeva, L. (ed.), Medialingvistika, Volume 6: Yazyk v koordinatakh massmedia. SanktPeterburg: SPbGU, pp. 171-172.

Duskaeva, L. (ed.). (2018). Medialingvistika v terminakh i ponatiyakh: slovar spravochnik. Moskva: Flinta.

Gasparov, M. (2002). 'Literaturnyy intertext i yazykovoy intertext', in Gasparov, M. (ed.), Izvestiya RAN. Seriya literatury i yazyka. Volume 61, Issue 4, pp. 3-9.

Juryeva, E. (2017). 'Verbalnyje i neverbalnyje prijomy sozdanija komicheskogo v kreolizovanych tekstoch socialnoj reklamy', in Izvestija Saratovskogo Universiteta, Novaja Serija, Serija Filologia, Zhurnalistika Volume 17, Issue 1, pp. 24-28.

Krasnykh, V. (1997). 'Systema precedentnykh fenomenov v kontexte sovremennykh issledovaniy', in Izotov, A. \& Krasnykh, V. (eds.), Yazyk, soznaniye, kommunikaciya. Volume 2. Moskva: Philologia, pp. 5-12.

Kristeva, J. (1980). Desire in Language: A Semiotic Approach to Literature and Art. New York: Columbia University Press.

Kuzmina, N. (2018). Intertext: tema s variaciyami. Phenomeny yazyka i kultury $\mathrm{v}$ intertextualnoy interpretacii. Moskva: Librokom.

Lipovetsky, G. (2008). Era prazdnoty: Uvahy o souchasnem individualismu. Praha: Prostor.

Lehoczka, V. (2010). 'Dimenzie profesionality suchasnej masmedialnej komunikacie', in Communication Today Volume 1, Issue 1, pp. 19-20.

Mardiyeva, L. (2012). 'Mekhanizmy vozdeystviya precedentnykh vizualnykh phenomenov na soznaniye chitateley', in Zamaletdinov, R. (ed.) Philology and Culture Volume 27, Issue 1, pp. 42-48.

Nakhimova, J. (2011). 'Kriterii precedentnosti imeni sobstvennogo', in Skvorcov, V. (ed.), Vestnik LGU Issue 1, pp. 169-173.

Norrick, N. (1989) 'Intertextuality in Humor', in Humor. International Journal of Humor Research Volume 2, Issue 2, pp. 117-139. 
Popova, T. (2017). 'Stilisticheskaya mnogoslojnost satiricheskogo politicheskogo kreolizovannogo texta kak sredstvo sozdanija ironii', in Duskaeva, L. (ed.), Medialingvistika Volume 19, Issue 4, pp. 7-17.

Sakharova, O. (2007). 'Adresovannaya ironiya (yazykovyye mechanizmy komicheskogo v epigrammakh)', in Arutunova, N. (ed.), Logicheskyy analiz yazyka. Yazykovyye mekhanizmy komizma, Moskva: Indrik. pp. 329-340.

Sasse, S. (2010). Michail Bachtin zur Einführung. Hamburg: Junius Verlag GmbH.

Vasilyeva, V. (2017). 'Anekdot v professionalnom mediatexte: pereprofelirovaniye rechevogo zhanra', in Duskaeva, L. (ed.), Medialingvistika Volume 19, Issue 4, pp. 80-89.

White, E. (1977). Essays of E.B. White. New York: Harper \& Row.

Ziv, A. (1984). Personality and sense of humor. New York: Springer Pub. Co. 